\title{
Results of preoperative antiglaucomatous treatment and of Scheie's operation
}

\author{
W. H. G. DOUGLAS* AND T. G. RAMSELL $\dagger$ \\ Oxford
}

Scheie's operation of sclerectomy-cautery with peripheral iridectomy, first described ind $195^{8}$ and first performed in Oxford in 1962, is now the drainage operation most frequentlyid used in the Oxford Eye Hospital. Thorpe (1955) and Scheie (1962) suggested that Diamox (acetazolamide) may adversely affect the outcome of drainage operations, reducingt the size of the resultant drainage bleb. Agarwal and Malik (1957) described a series 0 fifty patients all treated with the drug before iridencleisis and fifty controls. There was no great difference between the two groups and they concluded that fear of possible adverse affects of Diamox on the results of drainage operation could be discounted. In the present series we have attempted to produce more conclusive evidence and to suggest measures which may increase the success-rate of drainage procedures.

\section{Material}

Records were examined of all patients in whom Scheie's operation was performed on one or botr $\frac{\mathscr{D}}{2}$ eyes in the Oxford Eye Hospital between January, 1962, and April, 1967.

All cases of acute closed-angle glaucoma were excluded, as were all cases of glaucoma secondar 3 to diagnosed uveitis, past or present. There remained a group of roo operations performed eithe by a consultant or by his first assistant. All surgeons were initially using a new technique, and because there was little difference between the numbers of operations performed by each surgeon the group has been considered as a homogeneous one for this survey.

A satisfactory outcome of the operation is defined as control of intraocular pressure in the presence of a persistent subconjunctival fistula, without medical antiglaucomatous treatment for control oB ocular tension, this state having existed for one year or more.

\section{Findings}

Of the roo cases, 64 per cent. of eyes had a satisfactory fistula at the end of one year and did not require medication to keep the intraocular pressure below $22 \mathrm{~mm}$. Hg (Table I)

Table I Success rate of operation in 100 cases.

\begin{tabular}{ll} 
Draining at 12 months $\dagger$ & 64 \\
Fistula closed at 12 months & 36 \\
\hline Total & 100
\end{tabular}

†Without medical treatment 
Table II shows the distribution when the two categories in Table I are grouped according to preoperative treatment.

Table II Distribution of cases by preoperative treatment

\begin{tabular}{lcccc}
\hline Treatment & Draining $\dagger$ & Closed & Total & $\begin{array}{c}\text { Success rate } \\
\text { (per cent.) }\end{array}$ \\
\cline { 3 - 5 } Phospholine iodide & 24 & 13 & 37 & 65 \\
Phospholine iodide and Diamox & 6 & 7 & 13 & 47 \\
Pilocarpine & 21 & 6 & 27 & 78 \\
Pilocarpine and Diamox & 6 & 6 & 12 & 50 \\
Diamox & 0 & 2 & 2 & 78 \\
No treatment & 7 & 2 & 100 & \\
\hline Total & 64 & 36 & & \\
\hline
\end{tabular}

†Without medical treatment

Table III enumerates the cases in which Diamox was administered either pre- or postoperatively.

Table III Administration of Diamox

\begin{tabular}{|c|c|c|c|c|}
\hline Diamox & Draining† & Closed & Total & $\begin{array}{l}\text { Success rate } \\
\text { (per cent.) }\end{array}$ \\
\hline $\begin{array}{l}\text { Preoperative only } \\
\text { Postoperative only } \\
\text { Both }\end{array}$ & $\begin{array}{r}8 \\
18 \\
4\end{array}$ & $\begin{array}{l}8 \\
6 \\
7\end{array}$ & $\begin{array}{l}16 \\
24 \\
11\end{array}$ & $\begin{array}{l}50 \\
75 \\
36\end{array}$ \\
\hline Total & 30 & 21 & $5^{I}$ & \\
\hline
\end{tabular}

†Without medical treatment

Table IV is Table II amended to exclude those cases that had Diamox administered in the pre-operative period.

Table IV As Table II, excluding those having postoperative Diamox

\begin{tabular}{|c|c|c|c|c|}
\hline Treatment & Draining $†$ & Closed & Total & $\begin{array}{l}\text { Success rate } \\
\text { (per cent.) }\end{array}$ \\
\hline Phospholine iodide & 12 & I I & 23 & $5^{2}$ \\
\hline Phospholine iodide and Diamox & 4 & 3 & 7 & 57 \\
\hline Pilocarpine & 17 & 3 & 20 & 85 \\
\hline Pilocarpine and Diamox & 4 & 4 & 8 & 50 \\
\hline Diamox only & o & I & I & - \\
\hline No treatment & 5 & $\mathbf{I}$ & 6 & 83 \\
\hline Total & $4^{2}$ & 23 & 65 & \\
\hline
\end{tabular}

†Without medical treatment

Table IV shows that the outcome of the operation is similar under three different circumstances, the success rate being in the region of 50 per cent. These three groups are defined as follows:

(I) The patient is given phospholine iodide alone.

(2) Diamox and phospholine iodide are used together. 
(3) Diamox and pilocarpine are given as antiglaucomatous treatment in the preoperative period.

Two further groups emerge with a much higher success rate:

(5) Pilocarpine given alone.

(6) No preoperative antiglaucomatous treatment.

None of these cases received postoperative treatment with Diamox. The success rate of $\frac{\overline{\bar{n}}}{\sqrt{2}}$ similar groups is comparable even if Diamox is received by some of them in the postoperative $\overparen{D}$ period (Table II). If the preoperative treatment is disregarded, then Diamox does not seem to influence the success rate (Table V), but it does seem that preoperative and post- $\overrightarrow{0}$ operative administration of Diamox reduces the success rate (Table III).

Table $\mathbf{V}$ Administration of Diamox postoperatively without previous preoperative administration (27 had Diamox preoperatively)

\begin{tabular}{llllll}
\hline Diamox & & Drainingt & Closed & Total & $\begin{array}{l}\text { Success rate } \\
\text { (per cent. })\end{array}$ \\
\cline { 1 - 5 } \cline { 3 - 6 } Used & & 18 & 6 & 24 & 73 \\
Not used & & 35 & 14 & 49 & 70 \\
\cline { 1 - 5 } Total & 53 & 20 & 73 & \\
\hline
\end{tabular}

†Without medical treatment

These figures demonstrate that the preoperative administration of Diamox has an adverse effect on the outcome of this drainage operation and that phospholine iodide also influences the success rate of the procedure. Continued administration of Diamoxô before and after the operation also seems to be contraindicated.

\section{Complications}

In this series there was one case of acute angle-closure postoperatively after the instillation: of atropine, in spite of a patent iridectomy. Lowe (1962), Douglas and Strachan (1967) and Phillips and Snow (1967) have advocated the use of a sympathomimetic drug after iridectomy to avoid this complication in cases with a narrow angle.

Choroidal detachment was noted in the present series in 36 cases, 29 of these continued to drain in spite of this and were considered to be successes. Hyphaema occurred in 23 cases - this had reabsorbed completely by the fourth postoperative day in all but four cases. There was no case of infection or sympathetic ophthalmitis. It proved impossible to determine the incidence of cataract attributable to the surgery.

\section{Discussion}

Graham (1966) wrote that the best drainage operation was that one giving the best results in the hands of the operator. Scheie's operation has been analysed here for thise reason. In a series reported by Graham (1966) the success-rate for the first procedures ise 87 per cent. for his operation of choice but his criteria are somewhat different; the success rate in the present series is 64 per cent. It must be emphasized that our criterion for success is a fistula draining after 12 months without medical therapy. Not all procedures in our series were primary, six being second attempts. Graham did not describe the preoperative antiglaucomatous treatment given to his patients. 
We have thus confirmed the findings of Scheie (1962) and Thorpe (1955), i.e. that preoperative medication for control of tension influences the outcome of the operation. Individual drugs and combinations of drugs seem to give different results. Preoperative pilocarpine alone gives the highest success rate, and in the group receiving no treatment the success rate is similar. Phospholine iodide seems to have a deleterious effect, while a combination of drugs which includes Diamox is even less advantageous.

Becker (1954) first reported the effects of Diamox on the eye and subsequently Breinin and Görtz (1954), Becker (1955), and Friedenwald (1955) separately demonstrated that the lowering of intraocular pressure was independent of the facility of outflow measured by tonography, and therefore deduced that reduction of intraocular pressure was produced by reduced secretion of aqueous humour. More recently Davson (1956) and Galin and Harris (1966) have suggested that there is an alteration in the facility of outflow as well as reduction in the rate of aqueous secretion after administration of Diamox.

The duration of the effect of sustained-release preparations of Diamox compared with that of the standard tablets was studied by Drance and Carr (196i) who found that the maximum effect on the eye of the standard tablet (orally administered) is about 5 hours but that there is a demonstrable effect on tension for up to 12 hours. The slow-release preparation tested showed a maximum at 8 to 12 hours and was still demonstrable after 24 hours. Campbell, Tonks, and Jones (1956), comparing the systemic and ocular effects of Diamox, suggested an even longer effect on glaucomatous eyes, tension not returning to resting level for 20 to 24 hours after a single dose. The effect on intraocular pressure corresponds to a reduction in the serum sodium. Hanley and Platts (1956) also noted an acidosis which lasted for 2 to 4 days after a single dose of Diamox and 5 to 7 days after repeated doses.

Becker and Shaffer (1965a) suggested that it might be wise to stop the administration of carbonic anhydrase inhibitors after filtering operations, if the condition of the fellow eye permits. Formation of a functioning fistula as well as re-formation of the anterior chamber may well depend upon a free flow of aqueous.

Our figures suggest that preoperative Diamox is more harmful than postoperative Diamox in delaying re-formation of the anterior chamber.

\section{Conclusion}

After examining the records of roo cases in which Scheie's operation was performed, we consider that the outcome of this procedure is influenced by immediate preoperative antiglaucomatous treatment. Diamox and phospholine iodidehave both been incriminated in this respect in the past; we find that a combination of these drugs is definitely contraindicated. Becker and Shaffer ( $1965 \mathrm{~b}$ ) suggested that phospholine iodide should be stopped 3 weeks before this type of surgery is undertaken. We suggest that carbonic anhydrase inhibitors should be stopped for a week before surgery or reduced if the tension in the eye to be operated upon cannot be controlled to below $30 \mathrm{~mm}$. $\mathrm{Hg}$ with pilocarpine and isotonic adrenaline bitartrate ("Eppy"). It may be that before Scheie's operation is performed on eyes with high tension, oral or intravenous hyperosmotic agents are the drugs of choice. This is under consideration.

\section{Summary}

The records of 100 cases of Scheie's operation were analysed to determine the effect of preoperative antiglaucomatous drugs on the outcome of the procedure. The results are 
presented together with certain deductions. The action of Diamox is briefly outlined. A combination of drugs which includes Diamox is shown to be contraindicated. Suggestions are made for the preoperative care of patients for filtration operations.

We should like to thank Mr. Houlton, Mr. Lloyd, and Mr. Purvis for allowing us to study their case records and Mr. Lloyd and Dr. A. Pirie for help and encouragement in the preparation of this paper.

\section{References}

AGARWAL, L. P., and malik, s. R. K. (1957) Brit. J. Ophthal., 41, 6I 3

BECKer, B. (1954) Amer. F. Ophthal., 37, 13

(1955) Ibid., 39, No. 2, Part 2, p. 177

and Shaffer, R. w. (1965a) "Diagnosis and Therapy of the Glaucomas", 2nd ed.

p. 273. Mosby, St. Louis

$$
\text { - (1965b) Idem, p. } 27 \text { I }
$$

BREININ, G. M., and GÖRTZ, H. (1954) A.M.A. Arch. Ophthal., 52, 333

CAMPBEll, D. A., TONKS, E. A., and JONES, M. (1956) Brit. F. Ophthal., 40, 283

Davson, H. (1956) "Physiology of the Ocular and Cerebrospinal Fluids", p. 334. Churchill

London

DOUGLAS, w. H. G., and STRAGHAN, I. м. (1967) Brit. F. Ophthal., 51, 459

DRANCE, S. M., and CARR, F. (I96I) Ibid., 45, 695

friedenwald, J. s. (1955) Amer. F. Ophthal., 39, No. 4, Part 2, p. 59

GAlin, M. A., and HARris, L. (I966) Arch. Ophthal. (Chicago), 76, 493

GRAHAM, M. v. (1966) Trans. ophthal. Soc. U.K., 86, 223

haNley, T., and Platts, M. м. (1956) 7 . clin. Invest., 35, 20

LOWE, R. F. (1967) Brit. F. Ophthal., 51, 727

PhILlips, C. I., and sNow, J. T. (1967) Ibid., 51, 733

Scheie, H. G. (1958) Amer. J. Ophthal., 45, No. 4, Part 2, p. 220

(1962) Ibid., 53, 57 I

THORPE, H. E. (1955) A.M.A. Arch. Ophthal., 54, 22 I 